\title{
Terrorism among Youths in Nigeria: Implication for National Stability and Integration
}

\author{
Rotimi Adebayo Animasahun \\ Department of Guidance and Counselling, University of Ibadan, Ibadan, Nigeria \\ Email: animarotimi@yahoo.com
}

Received 30 August 2015; accepted 17 September 2015; published 22 September 2015

Copyright (C) 2015 by author and OALib.

This work is licensed under the Creative Commons Attribution International License (CC BY). http://creativecommons.org/licenses/by/4.0/

(c) (i) Open Access

\section{Abstract}

Youth violence, terrorism and gangsterism had seriously affected on Nigeria's security, economy and social development. This study appraised terrorism among youths in Nigeria, looking at poor education, unemployment and poverty as some of the specific identified factors prompting the menace. The survey research design was adopted for this study. Data were collected from both primary and secondary sources. Multistage simple systematic random sampling technique was adopted in administering a questionnaire consisting four validated instruments to 300 youths (150 males and 150 females) in the study area. Secondary sources of data included the report of United Nations Secretary General 2003, poverty rate, unemployment level and damage incurred due to violence and terror attack. Pearson product moment correlation and multiple linear regression analysis were used in testing the stated research questions and hypotheses. The result of the findings in research question (1) showed that there was a significant positive relationship between independent variables (poverty, unemployment and poor education) and dependent variable (terrorism) among youths in Nigeria: poverty $(\mathrm{r}=0.812, \mathrm{P}<0.05)$, unemployment $(\mathrm{r}=$ $0.835, P<0.05)$, and poor education $(r=0.829, P<0.05)$. The second research question as confirmed by the study showed that there was combined effect of poverty, unemployment and poor education on terrorism (Adj. $R^{2}=0.748=75 \%$ of the variance at $P<0.05, \mathrm{df}=3 / 269$ ). The result of the third research question also showed that there was a relative contribution of the independent variables to the explanation of the dependent variable; poverty $(\beta=0.384, t=7.584, P<0.05)$ followed by unemployment at $(\beta=1.585, \mathrm{t}=3.264, \mathrm{P}<0.05)$, and poor education at $(\beta=1.006, \mathrm{t}=$ $-2.213, P<0.05)$ in that order. The study demonstrated that poverty, unemployment and poor education were very strong factors contributing to the rate of terrorism in Nigeria with unemployment ranking highest. The study recommended that various kinds of poverty reduction strategies and empowerment should be put in place to reduce the rate of poverty in the society. Mass education, nomadic, adult education, among others need to be vigorously pursued to enlighten the people against all sort of nefarious activities and criminal act. Furthermore, there must be a public education on prints media, church, mosque and other means on need for youth to eschew violence, 
terrorism and gangsterism and other insurgency among others to enhance national stability and integration.

\title{
Keywords
}

\author{
Terrorism, Poor Education, Unemployment, Poverty, Insurgency, National Stability
}

Subject Areas: Sociology

\section{Introduction}

Youth violence, terrorism and gangsterism have reached unprecedented proportions in Nigeria, and seriously affected on Nigeria's security, economy and social development. Beginning from $29^{\text {th }}$ May, 1999, when the country re-commenced democratic rule, Nigeria has recorded very bizarre experiences in the domain of violence committed by young people. These acts of violence embrace murder, religious uprisings, party clashes, cult clashes, shooting, stabbing, kidnapping for ransom, armed robbery, including armed bank robbery, theft, burglary, rape, rioting especially against government policies, vandalism, militancy and so on. It should be noted that these types of violence are also characteristics of what Obateru [1] identified as urban violence.

Terrorism has increased sharply in recent years; it is by no means a new phenomenon. For decades terrorists have carried out attacks against noncombatant targets causing massive destruction by means of viscous assaults. While the objectives and modus operandi have changed, there is no reason to believe that terrorism will completely cease to exist in the near future. In fact, because terrorism is a tactic used by a wide variety of organizations it can be argued that terrorism cannot be defeated at all. While individual groups that use terrorist means to further their political objectives can be curbed, the vicious cycle has thus far not been broken. Some argue that the key to successfully dealing with terrorism lies in understanding its root and trigger causes. Others contend that it is equally important to consider factors of decline.

Two years after the events of $11^{\text {th }}$ September, 2001 Former United Nations Secretary General Kofi Annan delivered a speech to heads of state at a conference on "Fighting Terrorism for Humanity: A Conference on Roots of Evil". In it, Annan stressed the need to address the root causes of terrorism in order to be able to fight it. He warned that "if we are to defeat terrorism and gangsterism, it is our duty, and indeed our interest, to try to understand this deadly phenomenon, and carefully to examine what works, and what does not, in fighting it" (United Nations Secretary General [2]). The former Secretary General also emphasized that it was just as erroneous to believe that terrorism was unrelated to political and social factors, as it was to assume that terrorists were merely products of their environment. "Terrorism will only be defeated if we act to solve the psychosocial disputes or longstanding conflicts that generate support for it," stated Annan, adding that if we do not, we should find ourselves acting as recruiting sergeants for the very terrorists we seek to suppress.

There are root and trigger causes of terrorism. Root causes of terrorism explain the relationship between terrorism and youth's continuous suffering or deprivations such as: a lack of employment, poverty and poor education. These are preconditions for many forms of domestic terrorism (Club de Madrid [3]). Also, illegitimate or corrupt governments frequently give rise to opposition that may turn to terrorist means if other avenues are not seen as realistic options for replacing these regimes with a more credible and legitimate government or a regime which represents the values and interests of the opposition movement. Powerful external actors upholding illegitimate governments may be seen as an insurmountable obstacle to needed regime change. Such external support to illegitimate governments is frequently seen as foreign domination through puppet regimes serving the political and economic interests of foreign sponsors (Crenshaw [4]).

The trigger cause of terrorism is the existence of concrete grievances among an identifiable subgroup of a larger population, such as an ethnic minority discriminated against by the majority. This is not to say, however, that the existence of a dissatisfied minority or majority is a necessary or even a sufficient cause for terrorism; for not all those who are discriminated against turn to terrorism. The second condition that can create motivations for terrorism is the lack of opportunity for political participation. The last category of situational factors involves the concept of a precipitated event that immediately precedes outbreaks of terrorism. 
Terrorism is often the connecting link among varying personalities and apart from the results of socio-psychological studies of terrorism, the general situation remains one in which too little is known about causality (Adeniran [5], Adeoye \& Mohammed [6], Abimbola \& Adesote [7]). However, there are four categories of approaches to terrorism analysis: 1) the multi-causal approach; 2) the political or structural approach; 3) the organizational approach; and 4) the psychological approach.

\subsection{Multi-Causal Approach}

Emphasizing the presence of multiple causal variables, this approach incorporates psychological considerations, economic, political, religious and sociological factors as contributors to understanding the causes of terrorism (Albert [6]-[8]).

\subsection{Political or Structural Approach}

A political approach presupposes that the causes of terrorism can be found in environmental factors. For example, national or international arenas, as well as sub-national spheres like universities can be conducive to the rise of terrorism (Animasahun \& Saka [5] [9]), and Animasahun [10] indicated that poverty, oppression and inequality are causes of terrorism. [8] suggests that the inability to obtain what is felt to be justified triggers feelings of frustration that ultimately facilitates the emergence of collective violence.

\subsection{Rational or Organizational Approach}

With a focus on terrorism as a rational strategic choice, this approach rests on the idea that organizations consciously make the decision to use the instrument of terrorism as the best option to attain certain political goals. Adherents to the rational approach, including [11] who argued that terrorism is most definitely not the product of individual decisions or personal developments, but rather the result of a group process and its collective, rational decisions. This is highly speculative since hardly any empirical studies have provided evidence of how decisions are reached collectively in terrorist groups.

\subsection{Psychological Approach}

The psychological approach takes into account the motivation of individuals that resort to terrorism. Concerned with the personalities, beliefs and attitudes of terrorists and employed by scholars like Anifowose [6] [12], this approach focuses primarily on the features and characteristics of the individual perpetrator or terrorist group; examining the behaviour, recruitment methods, individual profiles, and "careers" of terrorists.

In Nigeria, certain constant factors breed and nurture youth violence; some of these factors are:

a) Social and moral decadence: This decay manifests itself in the form of various social vices and ills epitomized by corruption, indiscipline, moral laxity and many other ills in the society. For instance, a society where persons who have achieved success through corruption are lauded, the signal sent to the youths is that corruption is an acceptable means of achieving success. This is of course reflected in the violent behaviour of youths (Ifaturoti [10] [13], Animasahun [14], Animasahun \& Aremu [15]).

b) Influence of peer group: Many youths of this age whose average age group fall between 15 and 25 years are at their most impressionistic age and they tend to imitate easily. Thus, they are more easily manipulated and influenced by their peers, who encourage them to commit delinquent acts on the grounds that it enhances their status and commitment in the society [15].

c) Culture of drug abuse: Hard drugs such as heroin, marijuana and cocaine are often found in the possession of youths. Violent clashes often occur under the influence of alcohol and other mind disturbing drugs. [13], Aremu [16], Animasahun [17], and Animasahun and Animasahun [18] attest to the fact that abuse of drugs, such as cocaine, and overindulgence in alcoholic drinks, such as gin and whisky, alter the state of the user's mind and predispose it to violence.

d) Role of mass media: The mass media has also contributed to the upsurge in youth violence in Nigeria. The importation of violent films, which are shown on television and the everyday brutalities of Nigerian life, such as cult clashes, assassination and public violence, written about by the media with all the gory details and photographs, merge the frontiers of fantasy with reality for youths. It is possible that many of these delinquent youths merely act out what they have seen on video or television [13]. 
e) Ethnic nationalism and the formation of ethnic militias: The desire to wrestle power coupled with other considerations such as protest against cheating, territorial integrity and religious fanaticism have led to increased ethnic nationalism for which the youths constitute the bulk of these ethnic militias Akinboye [17] [19].

f) Role of the Elites: Certain elites in Nigeria are often behind youth violence and terrorism. They represent essentially capitalists who depend on the state machinery for survival. They have been found to be major player in the ethnic game for exploitation and manipulation of non-elites, usually directed towards personal/elite groups interests, which mostly promotes division and hatred among people in pluralistic societies [6] [7].

g) Economic factor: According to [1], poverty apparently accounts for the bulk of violence due to such problems as unemployment, inadequate housing, physical and social infrastructures. The current depression in the Nigerian economy must have worsened the situation of youths; this has rendered the youths idle and almost hopeless, hence they have become instruments of manipulation by the elites for ethno-religious and political insurrections [17].

h) Urban congestion: This has contributed to the promotion of youth violence in Nigeria, especially in the cities. A greater proportion of Nigerians live in the cities. The rapid rate of urban agglomeration was caused by the superior employment, education, health care and other attractions of the urban environment. Most of these urban migrants are youths (Akintoye [7] [20]). Therefore, the increase in the rate of youth rural-urban drift complicates the problems of housing, employment and population in the cities. All these problems produce stresses and strains that can be later expressed in the form of riots, cult clashes, and vandalism and so on. It is a truism that incidents of youth violence are not so common in the rural areas in Nigeria.

i) Family influence: Family influence plays an undeniable role in shaping the characters of youths. The quality of their family life is reflected in their behaviour. In families where violence is a way of life, a reflection of it is seen in the violent behaviour of the youth of the family [26]. More often than not, children living in violent homes are themselves more likely to become agents of violence as they grow up and become threats to peace and harmony in the society as they are recruited into gangster organizations [15].

However, this study focuses attention on poor education, unemployment and poverty as possible prevailing factors for youth's involvement in terrorism in Nigeria.

Education is recognized all over the world as both an instrument of change in the positive direction and a condition for change. National Policy on Education in Nigeria, Federal Republic of Nigeria [21] amplifies the need for education to be relevant, practical and for acquisition of appropriate skills needed for the development of the society. By implication, if the quality of education in any country is poor, national development will be impaired. In this case development programmes like Vision 2020 in Nigeria in which the country hopes to join the first twenty strongest economies in the world cannot be actualized. Qualitative education is therefore an imperative for development in any country. However, education in Nigeria is faced with numerous problems and challenges such as: poor staffing and low teacher quality, poor funding, inadequate infrastructures for high student population, cultism, corrupt practices in students' graduation and certification, poor students' commitment to learn, national insecurity and attendant issues. All these are the contributing factors to poor education in the Nigerian youths. More importantly, Nigeria education is grossly deficient! For instance, Archibald Callaway defined Education based on the main source of education i.e. from two Latin words: Educere and Educare. While Educere means to bring out, Educare means to nurture. Education therefore means leading out of the inborn powers and potentialities of the individuals as well as the acquisition of skills, aptitudes, and competencies necessary for self realization and for coping with life's challenges (Frankena, William, Raybeck, Nathan, Burbules, Nicholas [22]). But unfortunately, almost all Nigerian educationists have been trained to look for white collar jobs which are no longer there instead of receiving the kind of education that would bring out and develop the innate potentials of individuals. Hence, the acute incidence of graduate unemployment (Animasahun [23]).

Unemployment is another reason for the involvement of youths in terrorism. The National Bureau of Statistics [24] defined unemployment as the proportion of those who were searching for work but could not find any for at least active (labour force) population. [24] revealed that even when the economy was buoyant in Nigeria, the following rates of unemployment were recorded: $6.2 \%$ in the 1970 s, $9.8 \%$ in the $1980 \mathrm{~s}, 11.5 \%$ in the $1990 \mathrm{~s}$. The current rate of $23.9 \%$ by [24] indicates poor economic management and worse employment situation. Not only are young people the most likely to be affected when unemployment rates are high, there is also the danger that the psycho-social effects of unemployment on young people may be more damaging, both to the youth and the society at large. Terrorism, kidnapping, armed robbery and the spate of bombings in Nigeria of recent has 
brought to greater attention the challenge of unemployment in the country. Some analysts (Mohammed [25]) have argued that the high rates of unemployment are the grease that promotes and propagate not only the incidence of poverty but also crime and insecurity. According to [24], the hallmark of poverty and crimes in Nigeria is the level of unemployment among its active age citizens. If Nigeria can tackle the high rate of unemployment in the country by creation of productive employment, the battle against poverty and crime would have been won. The view by Mohammed has rekindled a troubling reality of an alarming employment crisis in Nigeria despite improved economic growth (i.e. non-inclusive growth). According to [24] the high incidence of unemployment amid economic growth is indicative of major socio-economic dislocations in the country. Unemployment rates in the country and among the states have continued to rise, thereby casting serious doubt about the effectiveness of the agencies and theft programmes. Persistency in sub regional unemployment rate may reflect stable equilibrium differentials in unemployment rates or may be attributed to the fact that shocks to sub regional unemployment rates have long-lasting effect (Ajibefun \& Daramola [20] [26]). Discriminating among the two cases is important because policy interventions are more likely to be effective in the case of long-lasting effect than in stable equilibrium differentials.

Poverty is associated with the undermining of a range key human attributes which expose the youth in the society to greater personal and environmental risk. Poverty means not having enough money for basic needs of life. Poverty and conflict are commonly understood to be closely interconnected. Conflicts as a result of poverty have led to high numbers of deaths, refugees and displaced people, material destruction and even state failure or collapse (Abanyan, Lumun \& Manbe [27]). Poverty is seen as been a cause of conflict, when grievances are not met, the poor and deprived in the society will riot, question the leadership as well and even join groups. Deteriorating economic development and extreme poverty may then strengthen tendencies to resort to violent means or activities among youths (Bourgois [28]). One way of helping lower poverty is by educating poor youth and creating employment opportunities for the youth in the country so that they can as well contribute to a nations economic development as this will reduce terrorism and gangsterism among the youth [28] and [27] reported that an organization called Nun International, founded by former special ops marine Jake Harriman, is pilot testing a holistic community based development model. Its mission is to end terrorism by ending extreme poverty. The connection is not difficult to make. For people living hand to mouth, life is a series of struggles often ending in tragedy. Anger, resentment, and despair are a volatile combination in the minds of young men and women who see little hope for escaping their situation. For recruiters of organizations like Boko Haram and the Al-Shabab literally translated as The Youth these young minds can be manipulated to pick up arms. By stoking latent frustrations at the injustice of poverty and promising a sense of a community, brotherhood, and commitment to a higher cause, a recruiter can more easily convince a youth to become a suicide bomber. The contemporary Nigeria society is engulfed by terrible acts of terrorism. Be it kidnapping by the Niger Delta Militants or bomb attacks by members of the Boko Haram sect (Bumah \& Abimbola [29]). These acts of terrorism have seriously caused untold hardship to the Nigerian populace. The discourse of the argument put forward in this paper is that contemporary terrorism in Nigeria is a product of prolonged failure of the Nigerian state to show characteristics or fulfill the purposes accepted as normal or beneficial to the totality of her citizens (Awoyemi [30]). This anger and frustration is compounded by a sense of injustice. When the gap between rich and poor is vast, the impoverished majority are more likely to consider their situation as a function of either indifference or criminality by those controlling the wealth. It is under these circumstances that the fledgling Nigerian terrorist group, Boko Haram, has grown.

The consequences of all these factors (poor education, unemployment and poverty) have been enormous incidences of terrorism among youths in Nigeria such as massive bombing, unabated killings, maiming, destruction of lives and properties, kidnapping, rape, robbery etc. The focus of this study therefore, was to investigate the predictive capacity of poor education, unemployment and poverty on the involvement of youths in terrorism in Nigeria. Therefore, three (3) research questions are formulated to guide the study.

\section{Research Questions}

1) What is the relationship between the independent variables (poor education, unemployment and poverty) and the dependent variable (Youth's involvement in terrorism)?

2) What is the combined effect of poverty, unemployment and poor education on terrorism?

3) What is the relative contribution of the independent variables to the dependent variable? 


\section{Research Design}

The descriptive research design of the expost-facto type was used for this study. This research design presents an empirical result from the surveyed sample and information obtained from the field through statistical analysis of events as they occur without manipulation.

\subsection{Participants}

The target population for the research comprised youths in the northern, eastern and southern part of Nigeria.

\subsection{Sampling and Sampling Technique}

The multistage random sampling technique was used to select three hundred respondents. The technique varied at four stages. In stage 1, three geo-political zones were selected in Nigeria and classified as North, East and South, where the incidence of terrorism is more rampant. At stage 2, a state was randomly selected from each of the three geopolitical zone mentioned earlier. At stage 3, a total of five local governments were selected from each of the three states of the federation. Hence, we have a total of 15 local governments of the federation. At stage 4 , twenty youths were randomly selected from each of the fifteen local governments on the basis of voluntary participation and convenience. These were youths found on major streets in the headquarters of such local governments. Therefore, a total of 300 youths responded to the questionnaires provided. They comprised 150 male and 150 females falling within the age range of 18 - 35 years.

\subsection{Instruments for Data Collection}

The instrument used for data collection was a questionnaire comprising 4 major scales called the multi problem screening questionnaire originally developed by [23], and was adapted for this study. It was divided into five sections namely section A the demographic characteristics, section B the terrorism scale, section C the unemployment scale, section $\mathrm{D}$ the poverty scale and section $\mathrm{E}$ the poor education scale.

The Terrorism scale consists of 15 items developed on 5-point Likert format, ranging from (1) Strongly disagree to (5) Strongly Agree. Its reliability level was established at $r=0.89$.

The Unemployment rating scale consists of 10 items developed on 5-point Likert format, ranging from (1) Strongly disagree to (5) Strongly Agree. Its reliability level was established at $r=0.78$.

The Poverty scale consists of 12 items developed on 5-point Likert format, ranging from (1) Strongly disagree to (5) Strongly Agree. Its reliability level was established at $r=0.86$.

The Poor education scale consists of 15 items developed on 5-point Likert format, ranging from (1) Strongly disagree to (5) Strongly Agree. Its reliability level was established at $r=0.82$.

\section{Method of Data Analysis}

The linear multiple regression analysis and Pearson product moment correlation (PPMC) were used to analyze the collected data.

\section{Result}

\subsection{Research Question 1}

What is the relationship between the independent variables (poverty, unemployment and poor education) and dependent variable (terrorism) among youths in Nigeria? The answer is presented in Table 1.

The result revealed that there was a significant positive relationship between independent variables (poverty, unemployment and poor education) and dependent variable (terrorism) among youths in Nigeria. The table revealed in the order of magnitude that unemployment $(\mathrm{r}=0.835, \mathrm{P}<0.05)$ has the strongest relationship with terrorism, followed by poor education $(\mathrm{r}=0.829, \mathrm{P}<005)$, and lastly, poverty $(\mathrm{r}=0.812, \mathrm{P}<0.05)$.

\subsection{Research Question 2}

What is the combined effect of poverty, unemployment and poor education on Terrorism? The answer is presented in Table 2. 
Table 1. Descriptive statistics and pearson product moment correlation matrix table showing the relationship between the independent and dependent variables.

\begin{tabular}{|c|c|c|c|c|c|c|c|c|c|}
\hline Variables & $\mathrm{N}$ & $\mathrm{X}$ & SD & 1 & 2 & 3 & 4 & $\mathrm{P}$ & Remark \\
\hline Terrorism & 300 & 42.04 & 2.910 & 1.000 & & & & & \\
\hline Poverty & 300 & 41.65 & 3.209 & $0.812^{* *}$ & 1.000 & & & $\mathrm{P}<0.05$ & Sig. \\
\hline Unemployment & 300 & 41.71 & 3.161 & $0.835^{* *}$ & $0.819^{* *}$ & 1.000 & & $\mathrm{P}<0.05$ & Sig. \\
\hline Poor education & 300 & 41.70 & 3.176 & $0.829^{* *}$ & 1.000 & $0.998^{* *}$ & 1.000 & $\mathrm{P}<0.05$ & Sig. \\
\hline
\end{tabular}

${ }^{* *}$ Correlation significant at $\mathrm{P}<0.05$ level.

Table 2. Summary of multiple regression analysis of the combined prediction of the independent variables on the dependent variable.

\begin{tabular}{ccccccc}
\hline R & R square & \multicolumn{2}{c}{ Adjusted R square } & \multicolumn{2}{c}{ Std. error of the estimate } \\
\hline 0.867 & 0.751 & \multicolumn{2}{c}{0.748} & 1.460 \\
\hline & \multicolumn{7}{c}{ SUMMARY REGRESSION ANOVA } \\
\hline \multirow{2}{*}{ Sum of squares } & Df & Mean square & F & P & Remark \\
Regression & 1902.023 & 3 & 643.008 & 297.612 & 0.000 & Sig. \\
Residual & 630.573 & 296 & 2.130 & & & \\
\hline
\end{tabular}

Table 2 showed that there was a combined effect of poverty, unemployment and poor education on terrorism. That is, youth's terrorism correlated positively with the three independent variables (poverty, unemployment and poor education). The table showed a coefficient of adjusted $\mathrm{r}$ square of 0.748 . This means that $74.8 \%$ (Adj. $\mathrm{R}^{2}=$ 0.748) of the variance in the terrorism of the respondents is accounted for by the three independent variables, when taken together. The significance of the composite contribution was tested at $\mathrm{P}<0.05$ using the F-ratio at the degree of freedom ( $\mathrm{df}=3 / 296)$. The table also shows that the analysis of variance for the regression yielded a F-ratio of 297.612 (significant at 0.05 level). This implies that the joint contribution of the independent variables to the dependent variables was significant and that other variables not included in this model may have accounted for the remaining variance.

\subsection{Research Question 3}

What is the relative contribution of the independent variables (poverty, unemployment and poor education) and dependent variables (terrorism) among youths in Nigeria? The answer is presented in Table 3.

Table 3 revealed there was a relative contribution of the independent variables (poverty, unemployment and poor education) to the dependent variable (terrorism) among youths in Nigeria. The beta weight showed that unemployment $(\beta=1.585, \mathrm{t}=3.264, \mathrm{P}<0.05)$ is the most potent contributor to the prediction, followed by poor education $(\beta=1.066, \mathrm{t}=2.213, \mathrm{P}<0.05)$, and finally, poverty $(\beta=0.384, \mathrm{t}=7.584, \mathrm{P}<0.05)$ and in that order.

\section{Discussion}

\subsection{Research of Hypothesis 1}

The result of findings in research question one showed that there was a relationship between independent variables (poverty, unemployment and poor education) and dependent variable (terrorism) among youths in Nigeria. This result supports the view of [27] who argued that poverty, oppression and inequality are causes of terrorism. Central to this research is the notion of relative deprivation, a term often used to used to describe feelings of economic, political or social deprivation, that are relative rather than absolute. They suggest that the inability to obtain what is felt to be justified triggers feelings of frustration that ultimately facilitates the emergence of collective violence. In addition to environmental factors, scholars have sought to identify precondition issues 
Table 3. Relative contribution of the independent variables to the dependent variable (test of significance of the regression coefficients).

\begin{tabular}{cccccccc}
\hline Variance & \multicolumn{1}{c}{ Understanding coefficients (B) } & Standardizes coefficients & & & \\
\hline Model & B & Std. error & Beta & T & Sig. & Remark \\
\hline Constant (terrorism) & 7.424 & 1.163 & - & 5.386 & 0.000 & \\
Poverty & 0.348 & 0.046 & 0.384 & 7.584 & 0.000 & Sig. \\
Unemployment & 1.459 & 0.447 & 1.585 & 3.264 & 0.001 & Sig. \\
Poor education & 0.977 & 0.441 & 1.066 & 2.213 & 0.028 & Sig. \\
\hline
\end{tabular}

that set the stage for terrorism in the long term, and precipitants mechanisms that activate the occurrence of terrorism. [28] argued that poverty effect focused on who loses out at the economic game, rather than addressing the fact that game produces loser in the first place where social intellectuals developed a full attack on the individual theory of poverty by exploring how social and economic system overrode and created individual poverty situations. He postulated that elimination of structural barriers to better jobs through education and training have been the focus of extensive manpower training and other programmes, generating substantial numbers of successes but also perceived failures. However, in spite of perceived importance of education, funding per student in less advantaged area lacks that which is spent on richer students, teachers are less adequately trained, books are often out of date or in limited supply, amenities are few and the culture of learning is under siege. This systemic failure of the schools is thus thought to be the reason poor people have low achievement, poor rates of graduation and few who pursue higher education resulted in terrorism.

\subsection{Research Question 2}

The result of findings in question two showed that there was a combined effect of poverty, unemployment and poor education on terrorism. This result supports the views of [10] and [25] who argued that there is a comprehensive perspective on the link between terrorism and poverty. According to [22], education is the largest sense in any act or experience that has a formative effect in the mind, character or physical ability of an individual. In its technical sense education is the process by which society deliberately transmits its accumulated knowledge, skill and values from one generation to another. Education is the process of imparting and acquiring knowledge and training to grow ones intellectual and mental capabilities, so as to make mature decision in different situations but it is unfortunate that many of our institution in Nigeria seem to forget the real pleasure of transferring not only the book texts into their students brains but the consciousness and sense that what the students are getting here. According to International Labour Organization (2012) in [15], unemployment occurs when people are without work and actively seeking job, unemployment rate is a measure of the prevalence of unemployment individual by all individual currently in the labor force, during the periods of recession, an economy usually experience a relatively high unemployment rate.

\subsection{Research Question 3}

The result of findings in question three showed that there was a relative contribution of the independent variables (poverty, unemployment and poor education) and dependent variable (terrorism) among youths in Nigeria. This result supports the views of [25] who argued that high rates of unemployment are the grease that promotes and propagate not only the incidence of poverty but also crime and insecurity. He said the hallmark of poverty and crimes in Nigeria is the level of unemployment among its active age citizen. According to [22], any connection between poor education and terrorism is indirect. It is evident that more educated people from privileged background are more likely to participate in politics, probably in part because political involvement requires some minimum level of interest, expertise, commitment to issues and effort, all of which are more likely if people are educated and wealthy enough to concern them with more than mere economic subsistence. However, this is not the case with those who are poor. They are always the followers and may revolt anytime to protest against the ruling power. 


\section{Conclusion}

This research investigated some psychosocial factors affecting terrorism among youths in Nigeria. It was found that: There was a relationship between independent variables (poverty, unemployment and poor education) and dependent variable (terrorism) among youths in Nigeria. There was a combined effect of poverty, unemployment and poor education on terrorism; and there was a relative contribution of the independent variables to terrorism among youths in Nigeria. Thus, the study clearly demonstrated that poverty, unemployment and poor education were very strong factors contributing to the rate of terrorism in the country, with unemployment ranking as the highest, followed by poor education and finally, poverty.

\section{Implication of the Study}

From the study, it is evident that as long as the youths suffer from unemployment, poor education and acute poverty, terrorism will not depart from Nigerian society.

\section{Limitation of the Study}

The study is limited in the choice of participants. For a study that would cover the whole federation, wider sample that spread all over the federation should have been chosen. Also, using respondents on streets is a great limitation to this study. However, the above limitations have not affected the authenticity of the study. It is suggested that this kind of study should be replicated to solve some of the societal problems. Therefore, future researchers should look for more variables responsible for terrorism and also use a large number of samples for such study. Finally, prospective researchers could adopt longitudinal and experimental methods to study terrorism in Nigeria.

\section{Recommendation}

It is hereby recommended that the government at various levels in the federation should strive to give functional education to all citizens. This should be the kind of education suitable for the current demand in the society. The curriculum should be adjusted to accommodate creativity, innovation, entrepreneurship, skills acquisition etc. Then all efforts must be made to ensure that citizens are meaningfully engaged because an idle hand is the devil's workshop. Various kinds of poverty reduction strategies and empowerment should be put in place to reduce the rate of poverty in the society. The outcome of all these efforts would be national stability and integration.

\section{References}

[1] Obateru, O.I. (1994) Planning the City to Mitigate Urban Violence. In: Albert, I.O., et al., Eds., Urban Management and Urban Violence in Africa, Vol. 1, IFRA, Ibadan.

[2] United Nations Secretary General (2003) Fighting Terrorism for Humanity: A Conference on Roots of Evil. Speech Delivered by United Nations Secretary General, Kofi Annan.

[3] Club de Madrid Series on Democracy and Terrorism, Vol. III (2005) In: Bumah, J. and Abimbola, A. (2009), The Boko Haram Tragedy and Other Issues. The Punch, August 6, Lagos.

[4] Crenshaw, M. (2001) The Causes of Terrorism. Comparative Politics, 13, 379-399. http://dx.doi.org/10.2307/421717

[5] Adeniran, T. (1996) Terrorism and National Security. Staff Seminar Series. Department of Political Science, University of Ibadan.

[6] Adeoye, M.N. and Muhammed, A.Y. (2005) Terrorism in Nigeria’s Fourth Republic: Implications for Sustainable Democracy and Development. Paper Presented at the National Conference on Democracy and Development, Organised by the Faculty of Business and Social Sciences University of Ilorin, April.

[7] Abimbola, J.O. and Adesote, S.A. (2011) Terrorism and National Security in the Niger Delta Area of Nigeria. In: Babatolu, J.S., Ed., National Security and Resource Management in Nigeria, School of Arts and Social Sciences, Adeyemi College of Education, Ondo.

[8] Albert, O. (1994) Urban Violence in Contemporary Africa: Some Theoretical Explorations. In: Albert, I.O., et al., Eds., Urban Management and Urban Violence in Africa, IFRA, Ibadan.

[9] Animasahun, R.A. and Saka, S.A. (2011) A Path Analytical Investigation of Some Psycho-Social Factors Predicting Adolescents' Criminal Intent in Ibadan metropolis. Nigerian Journal of Applied Psychology. 
[10] Animasahun, R.A. (2011) Development and Validation of Crime Behaviour Factor Battery. International Journal of Psychology and Counselling (IJPC), 3. http://www.academicjournals.org/IJPC

[11] Animasahun, R.A. (2013) Application of Problem Reversal Creativity Technique in Remedial and Reformatory Counselling Psychology. Journal of Development and Policy Issues in Africa, 7, 82-94.

[12] Anifowose, R. (2002) Urban Violence in Nigeria: The Case of the Oodua People Congress (OPC) Militia. Proceedings of the Conference on Industrialization, Urbanization and Development in Nigeria, 1950-1999 and Beyond, Lagos, 15-16 November 2002.

[13] Ifaturoti, T.O. (1994) Delinquent Sub-Culture and Violence in Nigerian Universities. In: Albert, I.O., et al., Eds., Urban Management and Urban Violence in Africa, Vol. 2, IFRA, Ibadan.

[14] Animasahun, R.A. (2012) Effect of TO-LO-PO-SO-GO Creativity Technique in the Reduction of Psychopathological Behaviours among Some Adolescents in Nigerian Prisons. African Journal for the Psychological Studies of Social Issues, 15, 238-248.

[15] Animasahun, R.A. and Aremu, C.A. (2015) Correlational Study of Age, Family Warmth and School Connectedness as Factors Affecting Juvenile Delinquency among Secondary School Adolescents in Osun State, Nigeria. International Journal of Psychology and Behavioral Sciences, 5, 80-88.

[16] Aremu, C.A. (2014) Path Analytic Investigation of Some Factors Affecting Juvenile Delinquency among Secondary School Adolescents in South-Western Nigeria. An Unpublished PhD Thesis, University of Ibadan, Ibadan.

[17] Animasahun, R.A. (2014) Marital Conflict, Divorce and Single Parenthood as Predictors of Adolescents’ Antisocial Behaviour in Ibadan. British Journal of Education, Society and Behavioural Science, 4, 592-602.

[18] Animasahun, R.A. and Animasahun, V.O. (2014) Predisposing Influence of Home Factors, Negative Self Component and Peer Orientation on Substance Abuse among Okada Riders in Ibadan. British Journal of Applied Science and Technology, 4, 1320-1333. http://dx.doi.org/10.9734/BJAST/2014/7151

[19] Akinboye, O.S. (2001) The Matrix of Ethnicity and Ethno-Religious Crises in Nigeria’s Nascent Democracy. In: Agwoholobo, E., Ed., The Humanistic Management of Pluralism: A Formula for Development in Nigeria, Murtab Press for the Faculty of Arts, University of Lagos ALF Publication, Lagos.

[20] Akintoye, I.R. (2008) Reducing Unemployment through the Informal Sector: A Case Study of Nigeria. European Journal of Economic and Administrative Sciences, 11, 97-106.

[21] Federal Republic of Nigeria (2004) National Policy on Education.

[22] Frankena, W.K., Raybeck, N. and Burbules, N. (2002) Philosophy of Education. In: Guthrie, J.W., Ed., Encyclopedia of Education, 2nd Edition, Macmillan Reference, New York.

[23] Animasahun, R.A. (2015) Prison Reforms in Nigeria. A Lecture Delivered in Remedial and Reformatory Courser (GCE 753), Department of Guidance and Counselling, University of Ibadan, Ibadan.

[24] National Bureau of Statistics (2012) Unemployment Rate in Nigeria. Federal Government of Nigeria.

[25] Mohammed, A.Y. (2012) Youth and Urban Violence in Nigeria: A Reflection on the Contemporary Ilorin Township. In: Ayinla, S.A., Ed., Issues in Political Violence in Nigeria, Hamson Ltd., Ilorin.

[26] Ajibefun, J.S. and Daramola, S.O. (2003) The Menace of Graduate Unemployment in Nigeria. In: Douglason, G.U. and Gbosi, A., Eds., The Dynamics of Productivity and Unemployment Nexus: Implications for Employment Generation in Nigeria, The Nigerian Economic Society, Ibadan.

[27] Abanyam, N.L. and Manbe, D.A. (2009) An Appraisal of Poverty Crisis in Nigeria and the Way Forward. Benue Journal of Sociology, 2.

[28] Bourgois, P. (2001) Culture of Poverty. In: Smelser, N.J. and Baltes, P.B., Eds., International Encyclopedia of the Social \& Behavioral Sciences, Waveland Press, Heights, 11904-11907. http://dx.doi.org/10.1016/B0-08-043076-7/00841-X

[29] Bumah, J. and Abimbola, A. (2009) The Boko Haram Tragedy and Other Issues. The Punch, Lagos.

[30] Awoyemi, A. (2012) The Boko Haram Uprising and Islamic Revivalism in Nigeria. Africa Spectrum, 45, 95-108. 